\title{
Effects of blood pathological changes before TAI on pregnancy of dairy cows with anestrus and estrus
}

[Efeitos de mudanças patológicas de plasma antes de (TAI) na gestação de vacas em anestro e estro]

\author{
Y. $D i^{1}$, C. $Z h a o^{1}$, Y. Bai ${ }^{1}$, D. Wang ${ }^{1}$, F. Zhang ${ }^{1}$, C. $X u^{1}$, C. $X i^{1,2, *}$ \\ ${ }^{1}$ College of Animal Science and Veterinary Medicine - Heilongjiang Bayi Agricultural \\ University - Heilongjiang, China \\ ${ }^{2}$ Heilongjiang Provincial Technology Innovation Center for Bovine Disease Control \\ and Prevention - Daqing, China
}

\begin{abstract}
The objective of this study was to investigate the influence of plasma pathological changes before timed artificial insemination (TAI) on pregnancy of cows. The contents of estrogen (E2), progesterone (P4), glucose (Glu), selenium (Se), brain-derived neurotrophic factor (BDNF), and histamine (HIS) in plasma of 48 Holstein cows were measured before TAI. According to the estrus detection, the cows were divided into estrus (E) and anestrus (A) groups. After pregnancy testing at $28 \mathrm{~d}$ after TAI, two groups of $\mathrm{E}$ and A were divided into positive pregnancy of $\mathrm{E}$ group (EP+), negative pregnancy of $\mathrm{E}$ group (EP-), positive pregnancy of A group (AP+), and negative pregnancy of A group (AP-). The contents of E2, P4, Glu, Se, BDNF and hIS significantly differed among the four groups $(\mathrm{P}<0.01)$. The ROC analysis was used to determine the risk of negative pregnancy test (-) after TAI was increased when plasma E2 was less than $46.45 \mathrm{pmol} / \mathrm{L}$ in cows before TAI. The changes in E2, P4,hIS, Glu, and BDNF in the blood of natural estrus and natural anestrus cows affected the pregnancy after TAI. the level of E2 in plasma may be used to assess the risk of negative pregnancy after TAI.
\end{abstract}

Keywords: dairy cow, estrus, TAI, ROC analysis

\section{RESUMO}

O objetivo do presente estudo foi investigar a influência de mudanças patológicas de plasma antes de inseminação artificial (TAI) na gestação de vacas. O conteúdo de estrogênio (E2), progesterona (P4), glucose (Glu), selênio (Se), fator neurotrófico derivado do cérebro (BDNF), e histamina (HIS) no plasma de 48 vacas Holstein foi medido antes de TAI. De acordo com a detecção de estro, as vacas foram divididas em dois grupos: estro (E) e anestro (A). Após teste de gestação 28 d após TAI, dois grupos de $E$ $e$ A foram formados em gestação positiva do grupo $E(E P+)$, gestação negativa do grupo $E(E P-)$, gestação positiva do grupo A (AP+), e gestação negativa do grupo A (AP-). Os valores de E2, P4, Glu, $S e, B D N F$ e hIS foram significativamente diferentes entre os quatro grupos $(P<0,01)$. A análise ROC foi utilizada para determinar o risco de teste de gestação negativo (-) após aumento de TAI quando plasma E2 estava abaixo de 46,45 pmol/L em vacas antes de TAI. Alterações em E2, P4,hIS, Glu e BDNF no sangue de estro natural e anestro natural em vacas afetou a gestação após TAI. O nível de E2 no plasma pode ser usado para avaliar o risco de gestação negativa após TAI.

Palavras-chave: vaca de leite, estro, TAI, análise ROC

\section{INTRODUCTION}

The technology of timed artificial insemination (TAI) is proposed, which mainly affects the estrus cycle of cows by use of exogenous reproductivehormones. According to the actual

Recebido em 26 de maio de 2020

Aceito em 9 de junho de 2020

*Autor para correspondência (corresponding author)

E-mail: xcwlxyf2014@163.com reproduction need, the same batch of cows can experience estrus, ovulation, and artificial insemination within the specified time (Lee et $a l ., 2005)$. This technology greatly reduced the workload of artificial observation of estrus, andhad the advantages of reliable effect, as well as being convenient, controllable, and efficient 
Lilja, Mathiesen. (2006). Estrus synchronization technology is an important part of intensive cattle farming, and also an important means to shorten the calving interval, which is of great significance in improving the reproductive efficiency of dairy cows Kawamura et al. (2005); Wiltbank, Pursley. (2014).

Presynch Ovsynch (PO) was proposed by Martinez et al. (2002) as follows: the first step is to inject ( Sodium chloroprostol injection ) PG once around 35-40 d after parturition, and again after $14 \mathrm{~d}$. After the two PG treatments, the estrus cycle of cows is unified. When gonarillin $(\mathrm{GnRH})$ is injected after $12 \mathrm{~d}$, the estrus cycle of all cows is ensured to be 5-12 d. The second injection of $\mathrm{PG}$ after $7 \mathrm{~d}$ dissolves the functional corpus luteum on the ovary. Luteinolysis leads to decreased progesterone $\left(\mathrm{P}_{4}\right)$ level in blood, which may stimulate development of dominant follicles due to the increased synthesis and secretion of estrogen; when PG is injected again to dissolve the corpus luteum, all treated cows can be guaranteed tohave dominant follicles and develop. After $48 \mathrm{~h}, \mathrm{GnRH}$ injection can make cows ovulate 24-32h, ensuring the synchronization of ovulation Martínez et al. (2002); Kafilzadeh et al. (2014).

The PO makes the estrus cycle more synchronous, reduces the breeding workload of large-scale cattle farms, and optimizes the breeding management. The PG can not only regulate the physiological function of ovaries and promote the development of dominant follicles, but also purifies the uterus. If estrus cows are in a status of negative energy balance, the administration of PGhas a certain preventive effect on ovarian quiescence(Sagirkaya et al. 2007).

At present, estrus synchronization is widely used in intensive dairy farms to improve the estrus rate and pregnancy rate of postpartum cows, but its effect is quite different among farms. (Seifer $e t$ al., 2002) however, after the TAI, fertility is usually not ideal in anestrus cows. Therefore, this study aimed to provide an early risk warning of postpartum anestrus cows after TAI in largescale cattle farms through investigation of estrus, pregnancy, and blood clinical pathological changes before TAI.

\section{MATERIAL AND METHODS}

Forty-eightholstein cows of similar age, parity, and body condition were selected in an intensive cattle farm inheilongjiang Province, China. All animals were managed in accordance with the standards approved by the Ethics Committee for Animal Welfare and Research ofheilongjiang Bayi Agricultural University China (Number: 20190625-5).The cows were fed by Free full mixed diet in loose column form ( TMR ) and water in separate columns. Diet composition was $21.40 \%$ corn, $3.20 \%$ concentrate, $6.44 \%$ soybean meal, $0.33 \%$ calciumhydrogen phosphate sodium bicarbonate $47.70 \%$ corn silage, $20.50 \%$ Leymus chinensis, and $0.28 \%$ salt. Diet nutrition levels were $75.60 \%$ dry matter, $11.65 \%$ crude protein, $4.10 \%$ crude fat, $21.42 \%$ crude fiber, $0.52 \%$ calcium, $0.43 \%$ phosphorus, $0.81 \%$ potassium, $0.40 \%$ magnesium, and $20.32 \mathrm{MJ} \cdot \mathrm{kg}^{-1}$ net lactation energy.

According to estrus detection before TAI, the cows were randomly assigned into estrus $(\mathrm{E})$ and anestrus (A). According to the pregnancy test 28 $\mathrm{d}$ after TAI, the cows were again assigned into estrus positive $(\mathrm{EP}+, \mathrm{n}=13)$, estrus negative (EP-, $\mathrm{n}=10)$, anestrus positive $(\mathrm{AP}+, \mathrm{n}=10)$ and anestrus negative (AP-, $\mathrm{n}=15)$ groups. In addition, estrus cows within $40 \mathrm{~d}$ after calvinghad estrus behaviors, ovulative follicle on the surface of ovaries, no abnormal signs of uterus by rectum examination, and no disease by clinical examination. Anestrus cowshad no estrus behaviors, no mature follicle on the surface of ovaries, no abnormal signs of uterus by rectum examination, and no disease by clinical examination. Then two groups of cows with $\mathrm{E}$ and $\mathrm{A}$ at $28 \mathrm{~d}$ after insemination were detected by B-ultrasound and rectal examination to determine pregnancy.

Estrous drugs in the same period: GnRH for injection (100 $\mu \mathrm{g} /$ tube, MON8054) and cloprostol sodium injection (PG, dobaosu, $0.2 \mathrm{mg} /$ tube sc271918), purchased from the Secondhormone Factory, Ningbo, China. Postpartum: 40 \pm 3 d (PG, 2 dobromycin/cow) $\rightarrow$ $54 \pm 3$ d (PG, 2 dobromycin/cow) $\rightarrow 66 \pm 3$ days $(\mathrm{GnRH}, 1$ shuniu/cow) $\rightarrow 73 \pm 3$ d $(\mathrm{PG}, 2$ dobromycin/cow) $\rightarrow 75 \pm 3$ d $(\mathrm{GnRH}, 1$ shuniu/cow) $\rightarrow \quad 16-24 \mathrm{~h} \quad$ (insemination/cow) (Martínez et al 2002) In the same period of 
estrus procedure, if cows presented estrus behaviors, insemination was applied.

Blood samples were collected before TAI. In the morning, $10 \mathrm{~mL}$ of blood was collected from the tail vein of the experimental animals, anticoagulated withheparin, centrifuged at a low speed of $4,000 \mathrm{rpm} / \mathrm{min}$ for $5 \mathrm{~min}$; the supernatant was drawn to be centrifuged at $12,000 \mathrm{rpm} / \mathrm{min}$ for $5 \mathrm{~min}$, and the plasma was separately packed and stored at $-80^{\circ} \mathrm{C}$.

Mineral elements in plasma of the tested cows including calcium $(\mathrm{Ca}$, arsenazo III), magnesium ( $\mathrm{Mg}$, arsenazo III), and phosphorus (P, UV terminal method) were analyzed using biochemical kits purchased from Landau Experimental Diagnosis Co., Ltd. (UK). Selenium (Se, atomic absorption method) and vitamin $\mathrm{E}$ (VE,high performance liquid chromatography) in plasma of the tested cows were determined by Shanghai Jingmahengyuan Technology Co., Ltd. (China).

Liver function and energy metabolism in plasma of the tested cows including aspartate aminotransferase (AST, rate method), total bilirubin (TBIL, chemical method), free fatty acid (NEFA, colorimetric method), and total cholesterol (TC, chemical method), were determined by the Addison Medical Testing Center; $\beta$-hydroxybutyric acid (BHBA, chemical method), glucose (Glu, glucose oxidase method), and triglyceride (TG, enzyme method) were determined by the Fourth Academy of National
University of Science and Technology in China. Hormone indexes in plasma of the tested cows including estradiol ( $\mathrm{E}_{2}$, chemiluminescence method) and progesterone ( $\mathrm{P}_{4}$, chemiluminescence method) were determined by the Addison Medical Testing Center; insulin (INS, ELISA) and insulin-like growth factor-1 (IGF-1, ELISA) were determined by Jingmahengyuan Technology Co., Ltd (Shanghai, China). Other indicators in plasma of the tested cows including bovine binding globulin (HP, ELISA), bovinehistamine (HIS, ELISA), reactive oxygen species (ROS, ELISA), and brain-derived neurotrophic factor (BDNF, ELISA) were determined by Jingmahengyuan Technology Co., Ltd.

The experimental data were statistically analyzed using IBM SPSS 19.0 (Stanford, Estados UNIDOS) software, and independent sample $t$ test analysis was performed between groups. Pearson's correlation coefficients were used for correlation analysis of parameters from two groups, a binary logistic regression model was used for predictive parameters of no pregnancy, and receiver operating characteristic (ROC) was used for risk warning of no pregnancy. Data are expressed as mean \pm standard deviation.

\section{RESULTS}

The Se level was significantlyhigher in plasma of the EP+ compared to the EP- group $(\mathrm{P}<0.05$, Table 1). There was no significant difference in other indicators between groups.

Table 1. Levels ofmineral elements, VE, and Se in plasma of experimental cows

\begin{tabular}{lcccc}
\multirow{2}{*}{ Indicators } & \multicolumn{2}{c}{$\mathrm{E}(\mathrm{n}=23)$} & \multicolumn{2}{c}{$\mathrm{A}(\mathrm{n}=25)$} \\
\cline { 2 - 5 } & $\mathrm{EP}+(\mathrm{n}=13)$ & $\mathrm{EP}-(\mathrm{n}=10)$ & $\mathrm{AP}+(\mathrm{n}=10)$ & $\mathrm{AP}-(\mathrm{n}=15)$ \\
$\mathrm{VE}(\mathrm{nmol} / \mathrm{L})$ & $575.22 \pm 65.68$ & $608.51 \pm 82.27$ & $553.51 \pm 62.83$ & $583.73 \pm 87.12$ \\
$\mathrm{Se}(\mu \mathrm{g} / \mathrm{L})$ & $0.58 \pm 0.11^{\mathrm{a}}$ & $0.47 \pm 0.10^{\mathrm{b}}$ & $0.55 \pm 0.10$ & $0.56 \pm 0.11$ \\
$\mathrm{Ca}(\mathrm{mmol} / \mathrm{L})$ & $2.17 \pm 0.08$ & $2.12 \pm 0.17$ & $2.14 \pm 0.05$ & $2.19 \pm 0.11$ \\
$\mathrm{Mg}(\mathrm{mmol} / \mathrm{L})$ & $1.15 \pm 0.10$ & $1.21 \pm 0.15$ & $1.18 \pm 0.06$ & $1.12 \pm 0.09$ \\
$\mathrm{P}(\mathrm{mmol} / \mathrm{L})$ & $1.68 \pm 0.18$ & $1.88 \pm 0.29$ & $1.67 \pm 0.28$ & $1.75 \pm 0.29$ \\
\hline
\end{tabular}

Notes: different capital letters indicate significant difference within the same group $\mathrm{E}$ or $\mathrm{A}$ $(\mathrm{P}<0.01)$, different small letters indicate significant difference $(\mathrm{P}<0.05)$, and no mark indicates no significant difference $(\mathrm{P}>0.05)$. Estrus positive group (EP+), estrus negative group (EP-), anestrus positive group (AP+), anestrus negative group (AP-), vitamin $\mathrm{E}$ (VE), selenium (Se), calcium (Ca), magnesium $(\mathrm{Mg})$, and phosphorus (P). Plasma BDNF level was significantly higher for the EP+ and EP- than for the $\mathrm{AP}+$ and $\mathrm{AP}$ - groups $(\mathrm{P}<0.05)$, and plasma hIS level was significantly higher for the EP+, $\mathrm{EP}-$, and AP- groups than for the $\mathrm{AP}+$ group $(\mathrm{P}<0.01$, Table 2). There were no significant 
differences for the other indicators between groups.

Notes: different capital letters indicate significant difference within the same group $\mathrm{E}$ or $\mathrm{A}$ $(\mathrm{P}<0.01)$, different small letters indicate significant difference $(\mathrm{P}<0.05)$, and no mark indicates no significant difference $(\mathrm{P}>0.05)$. Estrus positive group $(\mathrm{EP}+)$, estrus negative group (EP-), anestrus positive group (AP+), anestrus negative group (AP-), bovine haptoglobin (HP), reactive oxygen species (ROS), brain-derived neurotrophic factor (BDNF), and histamine (HIS). Plasma E2 content was significantly higher for the $\mathrm{EP}+$ than for the $\mathrm{AP}+$ and $\mathrm{AP}$ - groups $(\mathrm{P}<0.01)$ and also the EP- group $(\mathrm{P}<0.05$, Table 3$)$. Plasma $\mathrm{P} 4$ content was significantly higher for the $\mathrm{AP}+$ than the AP- group $(\mathrm{P}<0.01)$ and also the $\mathrm{EP}+$ and EP- groups $(\mathrm{P}<0.05)$. There were no significant differences for the other indicators between groups.

Notes: different capital letters indicate significant difference within the same group $\mathrm{E}$ or A $(\mathrm{P}<0.01)$, different small letters indicate significant difference $(\mathrm{P}<0.05)$, and no mark indicates no significant difference $(\mathrm{P}>0.05)$. Estrus positive group $(\mathrm{EP}+)$, estrus negative group (EP-), anestrus positive group (AP+) and anestrus negative group (AP-), insulin (Ins), insulin-like growth factor-1 (IGF-1), estradiol (E2), and progesterone (P4). Plasma Glu content was significantly higher for the $\mathrm{EP}+$ than the EPgroup $(\mathrm{P}<0.05)$, and plasma $\mathrm{TG}$ content was significantly higher for the AP- than the AP+ group $(\mathrm{P}<0.05$, Table 4$)$. There were no significant differences for the other indicators between groups.

Table 2. Levels ofhP, ROS, BDNF, andhIS in plasma of experimental cows

\begin{tabular}{|c|c|c|c|c|}
\hline \multirow{2}{*}{ Indicators } & \multicolumn{2}{|c|}{$E(n=23)$} & \multicolumn{2}{|c|}{$A(n=25)$} \\
\hline & $\mathrm{EP}+(\mathrm{n}=13)$ & EP- $(n=10)$ & $\mathrm{AP}+(\mathrm{n}=10)$ & AP- $(n=15)$ \\
\hline $\mathrm{HP}(\mu \mathrm{g} / \mathrm{L})$ & $37.11 \pm 6.60$ & $34.73 \pm 5.67$ & $35.02 \pm 7.81$ & $36.15 \pm 6.99$ \\
\hline ROS (IU/ml) & $188.72 \pm 39.24$ & $164.90 \pm 42.02$ & $172.40 \pm 42.03$ & $176.01 \pm 31.74$ \\
\hline BDNF (ng/L) & $175.43 \pm 28.49^{a}$ & $181.21 \pm 28.85^{\mathrm{a}}$ & $150.56 \pm 21.96^{b}$ & $151.89 \pm 22.46^{b}$ \\
\hline HIS $(\mu \mathrm{g} / \mathrm{L})$ & $27.60 \pm 4.40^{\mathrm{A}}$ & $31.04 \pm 2.60^{\mathrm{A}}$ & $21.93 \pm 2.00^{\mathrm{B}}$ & $27.45 \pm 4.70^{\mathrm{A}}$ \\
\hline
\end{tabular}

Table 3. Levels ofhormones in plasma of experimental cows

\begin{tabular}{lcccc}
\hline \multirow{2}{*}{ Indicators } & \multicolumn{2}{c}{$\mathrm{E}(\mathrm{n}=23)$} & \multicolumn{2}{c}{$\mathrm{A}(\mathrm{n}=25)$} \\
\cline { 2 - 5 } & $\mathrm{EP}+(\mathrm{n}=13)$ & $\mathrm{EP}-(\mathrm{n}=10)$ & $\mathrm{AP}+(\mathrm{n}=10)$ & $\mathrm{AP}-(\mathrm{n}=15)$ \\
\hline Ins $(\mathrm{mIU} / \mathrm{L})$ & $49.27 \pm 7.11$ & $51.46 \pm 8.28$ & $55.76 \pm 11.50$ & $53.13 \pm 7.26$ \\
IGF-1 $(\mu \mathrm{g} / \mathrm{L})$ & $33.37 \pm 6.03$ & $31.02 \pm 4.67$ & $31.76 \pm 6.69$ & $29.27 \pm 6.02$ \\
$\mathrm{E}_{2}(\mathrm{pmol} / \mathrm{L})$ & $49.19 \pm 28.17^{\mathrm{aA}}$ & $31.66 \pm 10.53^{\mathrm{b}}$ & $18.4 \pm 0.01^{\mathrm{B}}$ & $24.16 \pm 12.28^{\mathrm{B}}$ \\
$\mathrm{P}_{4}(\mathrm{nmol} / \mathrm{L})$ & $10.91 \pm 8.90^{\mathrm{a}}$ & $11.18 \pm 12.22^{\mathrm{a}}$ & $24.74 \pm 22.50^{\mathrm{aA}}$ & $9.17 \pm 9.47^{\mathrm{B}}$ \\
\hline
\end{tabular}

Table 4. Levels of liver function and energy metabolism in plasma of experimental cows

\begin{tabular}{lcccc}
\multirow{2}{*}{ Indicators } & \multicolumn{2}{c}{$\mathrm{E}(\mathrm{n}=23)$} & \multicolumn{2}{c}{$\mathrm{A}(\mathrm{n}=25)$} \\
\cline { 2 - 5 } & $\mathrm{EP}+(\mathrm{n}=13)$ & $\mathrm{EP}-(\mathrm{n}=10)$ & $\mathrm{AP}+(\mathrm{n}=10)$ & $\mathrm{AP}-(\mathrm{n}=15)$ \\
\hline Glu $(\mathrm{mmol} / \mathrm{L})$ & $3.71 \pm 0.63^{\mathrm{a}}$ & $2.69 \pm 1.36^{\mathrm{b}}$ & $3.66 \pm 0.55$ & $3.11 \pm 1.02$ \\
NEFA (g/L) & $0.33 \pm 0.10$ & $0.38 \pm 0.09$ & $0.34 \pm 0.09$ & $0.37 \pm 0.12$ \\
BHBA (mmol/L) & $0.83 \pm 0.42$ & $1.04 \pm 0.41$ & $0.76 \pm 0.26$ & $1.04 \pm 0.52$ \\
AST (U/L) & $80.79 \pm 19.10$ & $72.11 \pm 23.70$ & $70.57 \pm 11.19$ & $78.78 \pm 15.39$ \\
TBIL (g/L) & $3.66 \pm 1.73$ & $3.30 \pm 1.58$ & $4.11 \pm 1.61$ & $3.11 \pm 1.42$ \\
TC (mmol/L) & $5.26 \pm 1.45$ & $4.95 \pm 0.77$ & $5.07 \pm 1.00$ & $5.10 \pm 1.22$ \\
TG (mmol/L) & $0.06 \pm 0.03$ & $0.08 \pm 0.06$ & $0.04 \pm 0.03^{\mathrm{a}}$ & $0.09 \pm 0.07^{\mathrm{b}}$ \\
\hline
\end{tabular}

Notes: different capital letters indicate significant difference at same group $\mathrm{E}$ or $\mathrm{A} \quad(\mathrm{P}<0.01)$, different small letters indicate significant difference $(\mathrm{P}<0.05)$, and no mark indicates no significant difference $(\mathrm{P}>0.05)$. Estrus positive group (EP+), estrus negative group (EP-), anestrus positive group ( $\mathrm{AP}+$ ), anestrus negative group (AP-), glucose (Glu), free fatty acid (NEFA), $\quad \beta$-hydroxybutyrate (BHBA), alpha amino transferase (AST), total bilirubin (TBIL), 
total cholesterol (TC), and triglycerides (TG). Table 5 lists the indicators related to pregnancy. There was a significant negative correlation of the AP- group at $28 \mathrm{~d}$ after TAI with plasma levels of E2 and Glu. This showed that plasma level of E2 could predict pregnancy, especially negative pregnancy.

A binary logistic regression model was used to simulate the prediction of the above indexes on pregnancy test results of five treated cows, including E2 and Glu. The forward logistic regression method was used in the model and the hosmer and Lemeshow test showed that the chisquare value was $0.708(\mathrm{P}=0.05)$ and the chisquare critical value was $\operatorname{CHIINV}(0.05,4)=9.49$, thus the chi-square critical value exceeded the chi-square statistic (Table 5-2). From the perspective of significance, $0.950>0.05$ showed that the model fitted well. The model summary showed that the final ideal models of Cox\&Snell $\mathrm{R}$ square and Nagelkerke $\mathrm{R}$ were 0.238 and 0.326 , respectively (Table 5-3). The fitting effect of Cox\&Snell R square model is general, while that of Nagelkerke R square model is general. However, as a comparison between models, this parameter can be ignored.

The randomness table for the hosmer and Lemeshow test (Table 5-4) showed that "observed" and "expected" values were very close to each other, indicating that the model fitting was relatively ideal, and confirmed the results in Table 5-2. In step 1 of the model, the independent variables E2 and Glu had a better predictive effect on the negative diagnosis of pregnancy test results, up to $87.5 \%$, and a lower prediction effect on the positive diagnosis of $44.4 \%$, with a total percentage of $72 \%$ (Table 55). If the independent variable E2 was removed, the significance of the change was $0.009<0.05$ (Table 5-6); therefore, E2 could not be excluded, and it was significantly correlated with the coefficient of the model summary independent variable. The independent variable Glu was not significantly correlated with the model in the equation (Table 5-7), so it was excluded. The above analysis indicated that the plasma E2 level could be used to predict the results of PO pregnancy tests, with better prediction for negative tests.

Threshold value, sensitivity, specificity, and area under the curve (AUC) of parameters predicting pregnancy early warning are given in Table 6 and Figure 1. The AUC of E2 was 0.757, which is of great significance for the diagnosis and prediction of pregnancy. Therefore, if plasma E2 for a cow was less than $46.45 \mathrm{pmol} / \mathrm{L}$ before TAI, then it would be not pregnant following TAI.

Table 5. Correlation of blood parameters before TAI with negative pregnancy after TAI in dairy cows with anestrus

\begin{tabular}{lcc}
\multicolumn{1}{c}{ Parameter } & R value & P value \\
\hline $\mathrm{E}_{2}(\mathrm{pmol} / \mathrm{L})$ & $-0.447^{*}$ & 0.025 \\
Glu $(\mathrm{mmol} / \mathrm{L})$ & $-0.410^{*}$ & 0.042 \\
BHBA $(\mathrm{mmol} / \mathrm{L})$ & $+0.443^{*}$ & 0.034 \\
TG $(\mathrm{mmol} / \mathrm{L})$ & $+0.415^{*}$ & 0.049 \\
$\mathrm{HIS}(\mu \mathrm{g} / \mathrm{L})$ & $+0.597^{*}$ & 0.03 \\
\hline
\end{tabular}

SPSS 19.0 was used to establish a binary logistic regression model to simulate the prediction of the above two indexes on the pregnancy test results of dairy cows with Presynch Ovsynch.

Estradiol ( $\left.\mathrm{E}_{2}\right)$, glucose (Glu), $\beta$-hydroxybutyrate (BHBA), triglycerides (TG), andhistamine (HIS). 
Table 5-1 Omnibus test of model coefficients

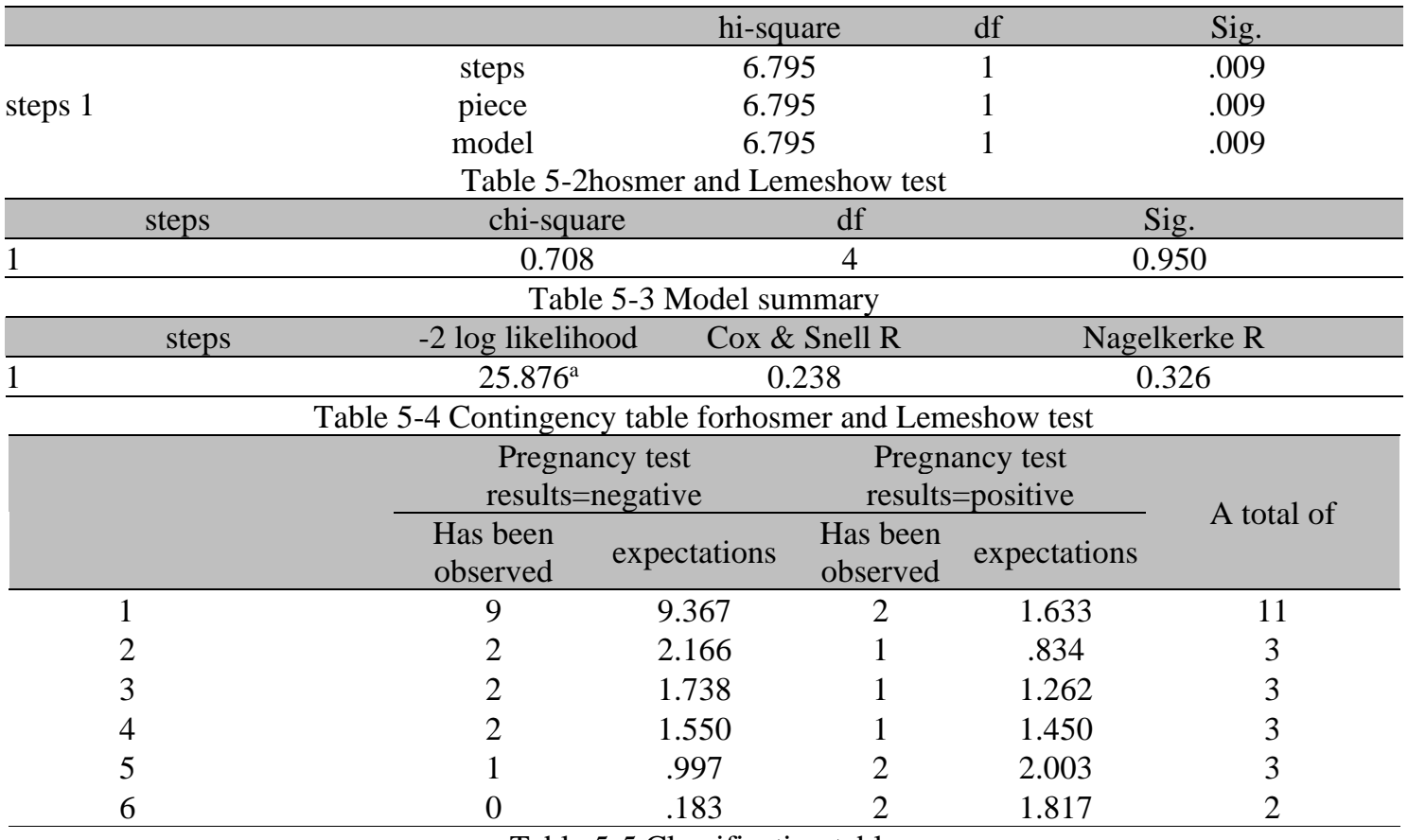

Table 5-5 Classification table

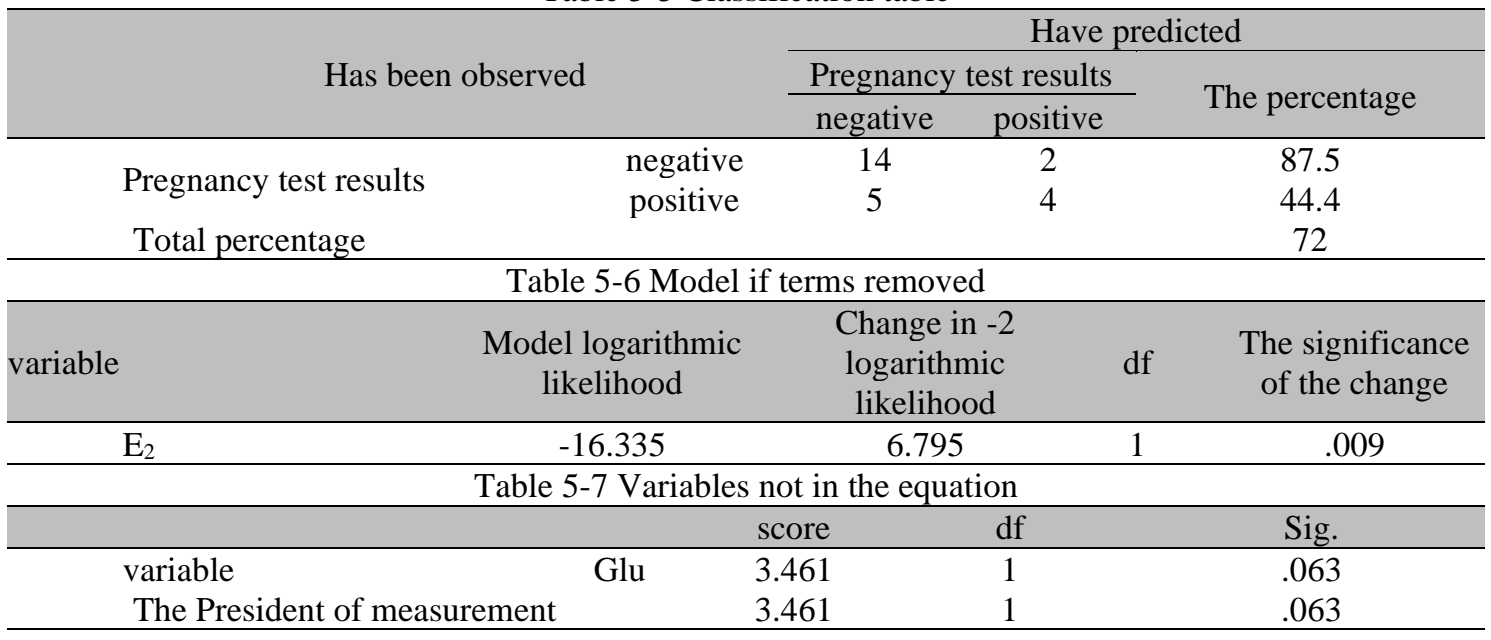

Table 6 Correlation between Presynch Ovsynch cows' pregnancy negative and biochemical traits in plasma

\begin{tabular}{lccccc} 
Parameter & $\begin{array}{c}\text { Threshold } \\
\text { value }\end{array}$ & $\begin{array}{c}\text { Sensitivity } \\
(\%)\end{array}$ & $\begin{array}{c}\text { Specificity } \\
(\%)\end{array}$ & $\begin{array}{c}\text { Standard } \\
\text { deviation }\end{array}$ & AUC \\
\hline $\mathrm{E}_{2}(\mathrm{pmol} / \mathrm{L})$ & 46.45 & 44.44 & 100 & 0.109 & 0.757 \\
\hline
\end{tabular}

Estradiol ( $\left.\mathrm{E}_{2}\right)$, area under the curve (AUC) 


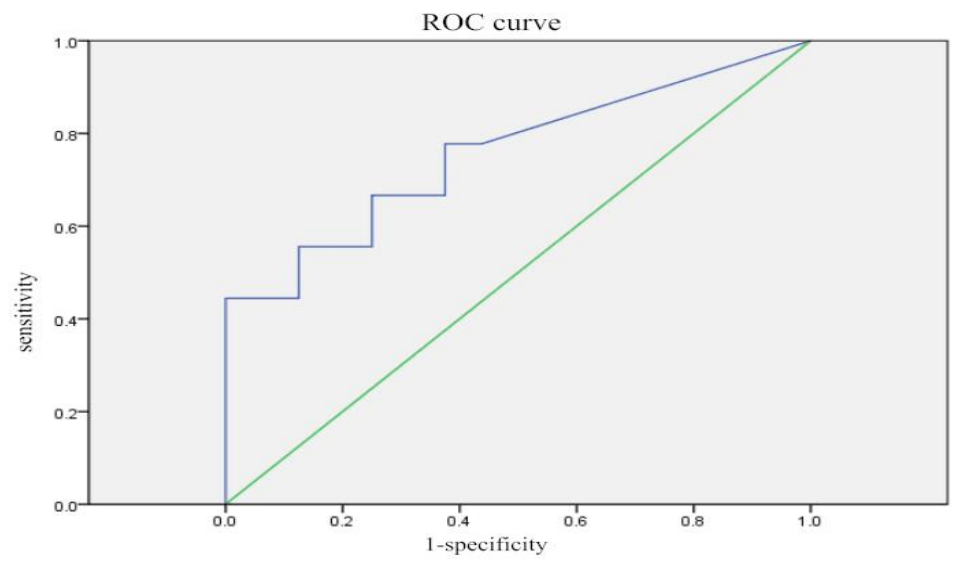

Figure 1 Receiver operating characteristic (ROC) plots for $E_{2}$ for diagnosis of negative pregnancy test in experimental cows treated with the Ovsynch.

\section{DISCUSSION}

The plasma levels of E2, P4, Glu, Se, BDNF, $\mathrm{TG}$, and hIS in the four groups of cows changed significantly before TAI $(\mathrm{P}<0.01)$. Correlation analysis and binary logistic regression models were used to determine the indexes related to the early warning of negative pregnancy after TAI in the tested cows. An ROC analysis was also conducted to obtain the early warning values of E2 and hIS before TAI. It is well-known that Se can affect the reproductive function of animals, and lack of Se can lead to poor fertility of cows. When Se or VE are absent in the diet, cows are prone to anestrus (Kumar et al., 2002). In this experiment, the cows in E or A groups showed natural estrus or anestrus, but the plasma Se level was significantly lower for the EP- than for the $\mathrm{EP}+$ group, and there was no difference between $\mathrm{AP}+$ and $\mathrm{AP}$ - groups.

This suggested that low plasma Se level of cows before TAI had a negative effect on cows with estrus after TAI, and no effect on cows with anestrus. Therefore, it is necessary to pay attention to Se supplement for dairy cows in production practice. The BDNF can promote oocyte maturation and early embryo development. Karakaya-Bilen et al. (2019) reported that BDNF promoted buffalo oocyte maturation. Seifer et al. (2002) found that BDNF significantly enhanced the first polar body excretion rate of mouse oocytes.

Hong et al. (2009) reported that the increase of nucleus maturation rate of oocytes of yellow cattle was related to BDNF. These studies indicated that BDNF plays an important role in oocyte maturation. The plasma level of BDNF was significantly higher in $\mathrm{E}$ than in A groups, indicating that BDNF affected estrus in dairy cows, consistent with previous reports. However, there was no significant difference in plasma BDNF concentration between $\mathrm{AP}+$ and $\mathrm{AP}-$ groups or between $\mathrm{EP}+$ and EP- groups. Therefore, the relationship between BDNF and pregnancy after TAI in dairy cows requires further study.

Histamine is an important inflammatory marker. Giordano et al. (2015) found that hIS is closely related to the cycle change and reproductive function, and has an impact on the physiological function of ovary, fallopian tube, and uterus. Harel et al. (2006) reported that follicular fluid accumulation in rats was related to hIS, which may be involved in the development of cyst follicles. Feng et al. (2003) reported that hIS can reduce the production of $\mathrm{E} 2$ in the uterus and increase the synthesis of PGF $2 \alpha$ in estrous rats. The plasma level of hIS was significantly lower in the AP+ than in the other three groups, but the plasma level of hIS at $28 \mathrm{~d}$ after TAI was lower in the EP+ than the EP- group. Therefore, hIS could be an important mediator in estrus, ovarian development, and pregnancy in dairy cows.

It is well-known that reproductive hormones regulate postpartum estrus, in which E2 and P4 play important roles in cows' estrus behaviors. The ovulation mechanism of postpartum cows is that the hypothalamus secretes a GnRH pulse into the human pituitary portal system to stimulate the pituitary to secrete a luteinizing 
hormone (LH) pulse. The LH acts on the ovary through blood circulation, promotes follicular development, and produces E2, which in turn causes the sudden rise of LH secretion, forming the LH peak before ovulation, leading to ovulation (Ikeda et al., 2005).

In this experiment, the E2 concentration in the plasma of cows was significantly lower in the anestrus than the estrus group, indicating that the low level of E2 in the ovaries of the postpartum anestrus cows could not positively feedback on the hypothalamus pituitary ovary axis, could not release the LH peak before ovulation, and could not induce estrus and ovulation (Jang et al., 2006). The low level of E2 in the plasma of cows was significantly higher in the EP+ than the EPgroup, indicating that the low E2 level hindered the effect of TAI when the cows had natural anestrus before TAI. However, the effect of E2 on anestrus needs further study.

For postpartum estrus cows, the P4 level in the blood was relatively low, and the high level of progesterone inhibited the development of follicles, and so caused the estrus cycle to stop and cause infertility (Wathes et al., 2007) In addition, the plasma P4 concentration was significantly higher in the $\mathrm{AP}+$ than in the other groups, but the standard deviation was large. The analysis suggested that the high P4 content of individual cows was due to pathological reasons.

Glu is an important energy source for dairy cows. In the early stage of lactation, the intake of nutrients, especially Glu, is not enough to meet the needs of lactation. Therefore, cows are in a state of negative energy balance (NEB) and must mobilize fat tissue to provide Glu for milk production. The NEB is a risk factor for ovarian dysfunction (Leroy et al., 2008), because NEB will lead to the disorder of nutrition metabolism and hormones. Therefore, the reproductive performance of cows suffering from NEB is very poor (Furman ,Wade, .2007), showing prolonged empty periods and ovarian quiescence. After parturition, NEB can inhibit GnRH neurosecretion and inhibit follicular development through changes in reproductive and metabolic hormones. Studies have shown that hypoglycemia and NEB can affect the hypothalamus and thus inhibit the physiological activities of the reproductive system Katz, Vollenhoven (2000); Rizos et al. (2002).
In this experiment, the Glu concentration was significantly higher in the EP+ than in the EPgroup, indicating that the NEB could still affect the reproductive performance of dairy cows during natural estrus, and the lack of Glu would lead to a decrease in the natural estrus effect for natural estrus dairy cows at the same time, while the effect of Glu on the estrus of anestrus cows still needs to be proved. Therefore, cattle farms require scientific and reasonable adjustment of feeding management by timely monitoring of the energy balance of cows, so as to obtain better reproductive performance.

Studies have shown that the increase of TG concentration (1-2 weeks after parturition) will lead to fatty liver in dairy cows, which may result in NEB; disturb the secretion of LH, E2 and P4; block the development of follicles; and lead to ovarian dysfunction in dairy cows (Stangaferro et al., 2019). In this experiment, TG content was significantly higher in the AP- than the $\mathrm{AP}+$ group, and so cows in the AP- group might have had fatty liver. However, the effect of TG in the blood of estrus cows needs further study.

\section{CONCLUSION}

The PO and estrus synchronization have been widely used in cattle farms to effectively improve reproductive efficiency. However, the effects of estrus synchronization differ among farms and even within farms. Therefore, Pearson's correlation analysis and binary logistic regression models were used to establish correlations between the plasma Se, hIS, E2, P4, Glu, TG, and the effect of TAI. Combined with ROC analysis, the early warning values of E2 before TAI were used to assess 28-d pregnancy status after TAI. If plasma E2 level would be less than $46.45 \mathrm{pmol} / \mathrm{L}$. This provides a new basis for the rational application of estrus synchronization technology and the improvement of pregnancy rate of anestrus cows.

\section{ACKNOWLEDGMENT}

This study was supported by the national science foundation of china (grant no. 31772804), the national science foundation of china (grant no. 31873028). research and demonstration of key technologies for comprehensive prevention and control of major reproductive disorders of dairy 
cows in heilongjiang reclamation area (hkky190302) Research and demonstration on key technologies for comprehensive prevention and control of major reproductive disorders in dairy cows in the reclamation area of heilongjiang province, china (no. 201914), and the heilongjiang provincial technology innovation center for bovine disease control and prevention. We thank international science editing

(http://www.internationalscienceediting.com) for editing this manuscript.

\section{REFERENCES}

FENG, B.; CHEN, S.; SHELDEN, R.M.; SEIFER, D.B. Effect of gonadotropins on brainderived neurotrophic factor secretion byhuman follicular cumulus cells. Fertil. Steril., v.80, p.658-659, 2003.

FURMAN, M.; WADE, G.N. Animal models in the study of nutritional infertility. Curr. Opin. Endocrinol. Diabetes Obes., v.14, p.475-481, 2007.

GIORDANO, J.O.; THOMAS, M.J.; CATUCUAMBA, G. et al. Effect of extending the interval from Presynch to initiation of Ovsynch in a Presynch-Ovsynchprotocol on fertility of timed artificial insemination services in lactating dairy cows. J. Dairy Sci., v.99, p.746-757, 2015.

HAREL, S.; JIN, S.; FISCH, B.; FELDBERG, D. et al. Tyrosine kinase B receptor \& its activated neurotrophins in ovaries from human fetuses and adults. Mol. Hum. Reprod., v.12, p.357-365, 2006.

HONG, S.G.; JANG, G.; OHH, J. et al. The effects of brain-derived neurotrophic factor and metformin on in vitro developmental competence of bovine oocytes. Zygote, v.17, p.187-193, 2009.

IKEDA, S.; KITAGAWA, M.; IMAI, H.; YAMADA, M. The roles of vitamin A for cytoplasmic maturation of bovine oocytes. $J$. Reprod. Dev., v.51, p.23-35, 2005.

JANG, G.; BHUIYAN, M.M.; JEON, H.Y.; KO, K.H. et al. An approach for producing transgenic cloned cows by nuclear transfer of cells transfected withhuman alpha 1-antitrypsin gene. Theriogenology, v.65, p.1800-1812, 2006.
KAFILZADEH, F.; KHEIRMANESHH, KARAMI, S.H. et al. Comparing the effect of oral supplementation of vitamin $\mathrm{E}$, injective vitamin $\mathrm{E}$ and selenium or both during late pregnancy on production and reproductive performance and immune function of dairy cows and calves. Sci. World J., v.2014, 5p., 2014.

KARAKAYA-BILEN, E.; YILMAZBASMECITOGLU, G.; KESKIN, A. et al. Fertility of lactating dairy cows inseminated with sex-sorted or conventional semen after Ovsynch,PresynchOvsynch and Double-Ovsynch protocols. Reprod. Domest. Anim., v.54, p.309-316, 2019.

KATZ, M.G.; VOLLENHOVEN, B. The reproductive endocrine consequences of anorexia nervosa. Bjog Int. J. Obstet. Gynaecol., v.107, p.707, 2000.

KAWAMURA, K.; KAWAMURA, N.; MULDERS, S.M.; SOLLEWIJN GELPKE, M.D.; HSUEH, A.J. Ovarian brain-derived neurotrophic factor (BDNF) promotes the development of oocytes into preimplantation embryos. Proc. Natl. Acad. Sci., v.102, p.92069211, 2005.

KUMAR, K.S.D.; KUMAR, A.; PRAKASH, S. et al. Role of red cell selenium in recurrent pregnancy loss. J. Obstet. Gynecol., v.22, p.181183, 2002.

LEE, M.S.; KANG, S.K.; LEE, B.C.; HWANG, W.S. The beneficial effects of insulin and metformin on in vitro developmental potential of porcine oocytes and embryos. Biol. Reprod., v.73, p.1264-1268, 2005.

LEROY, J.L.; OPSOMER, G.; VAN, S.A. et al. Reduced fertility inhigh-yielding dairy cows: are the oocyte and embryo in danger? Part I. The importance of negative energy balance and altered corpus luteum function to the reduction of oocyte and embryo quality inhigh-yielding dairy cows. Reprod. Domest. Anim., v.43, p.612$622,2008$.

LILJA, A.E.; MATHIESEN, E.R. Polycystic ovary syndrome and metformin in pregnancy. Acta Obstet. Gynecol. Scand., v.85, p.861-868, 2006.

MARTÍNEZ, M.F.; KASTELIC, J.P.; ADAMS, G.P. et al. The use of progestins in regimens for fixed-time artificial insemination in beef cattle. Theriogenology, v.57, p.1049-1059, 2002. 
RIZOS, D.; WARD, F.; DUFFY, P.; BOLAND, M.P. LONERGAN, P. Consequences of bovine oocyte maturation, fertilization or early embryo development in vitro versus in vivo: implications for blastocyst yield and blastocyst quality. Mol. Reprod. Dev., v.61, p.234-248, 2002.

SAGIRKAYA, H.; MISIRLIOGLU, M.; KAYA, A. et al. Developmental potential of bovine oocytes cultured in different maturation and culture conditions. Anim. Reprod. Sci., v.101, p.225-240, 2007.

SEIFER, D.B.; FENG, B.O.; SHELDEN, R.M. et al. Brain-derived neurotrophic factor: a novelhuman ovarian follicular protein. J. Clin. Endocrinol. Metabol., v.87, p.655-659, 2002.
STANGAFERRO, M.L.; WIJMA, R.W.; GIORDANO, J.O. Profitability of dairy cows submitted to the first service with the presynchovsynch or double-ovsynch protocol and different duration of the voluntary waiting period. J. Dairy Sci., v.102, p.4546-4562, 2019.

WATHES, D.C.; FENWICK, M.; CHENG, Z. et al. Influence of negative energy balance on cyclicity and fertility in thehigh producing dairy cow. Theriogenology, v.68, Suppl.1, p.S232S241, 2007.

WILTBANK, M.C.; PURSLEY, J.R. The cow as an induced ovulator: timed AI after synchronization of ovulation. Theriogenology, v.81, p.170-185, 2014. 